\title{
Safety Evaluation of Urban Large Scale Sewage Treatment Plant
}

\author{
Gao Ping*, ${ }^{*}$, Zhang Luyan ${ }^{2}$ and Fu Gui ${ }^{1}$ \\ ${ }^{I}$ Faculty of Resource \& Safety Science Engineering, China University of Mining \& Technology, Beijing, Beijing, \\ 100083, P.R. China \\ ${ }^{2}$ Security Protection Department, BeiJing College of Politics and Law, Beijing, 102628, P.R. China
}

\begin{abstract}
In recent years, accidents of urban large scale sewage treatment plant at home and abroad have took a big loss to countries and individuals. Based on field research and scientific analysis of one large sewage treatment plant this paper use the safety check list to evaluate its safety and get that the main risk factors which should be focused on are poisoning and suffocation, electrical injuries, fire and explosion. Using accident tree method to analyze electrical equipment accidents we know that in order to prevent electric shock accident first is to use the safety equipment and control leakage events due to dirty and wet.
\end{abstract}

Keywords: Accident tree, hazard identification, sewage treatment plant, safety evaluation, safety check list.

\section{INTRODUCTION}

The safety production license Ordinance provides that the wastewater treatment plant must conduct safety evaluations, the purpose of which isto improve the levels of safety and security in the wastewater treatment process. However, in practice, because the evaluation method and evaluation criteria is not perfect and be lack of quantitative evaluation methods as well as the most unsatisfactory evaluation of professional quality and other factors the safety situation, employees' security awareness and level of safety technology of wastewater treatment plant is not easy to be changed fundamentally after safety evaluation.

Safety evaluation of wastewater treatment plants are designed to find,analyze, and forecast of dangerous and harmful factors in the sewage treatment process and the possible risks and dangers and extent of proposed reasonable safety measures guide hazard control and accident prevention, in order to achieve the lowest accident rates, minimum loss and best safety processing efficiency.

This paper based on the scientific method to evaluate the safety of a large sewage treatment plant, with a view to provide references for safety evaluation of wastewater treatment plants.

\section{FACTORY OVERVIEW}

The evaluated wastewater treatment plant in this paper can be divided into three functional areas.

1. Front factory district. The district located in northeastern, including complex building, dining room, bathroom, garage, mechanical workshop, warehouse, janitor, etc.

2. Sewage treatment areas. This zone located in the plant center mainly covers pretreatment tank, sedimentation tank I , bio pool and sedimentation tank II, which is the main part of plant. Its northeastern is front factory district and northwest is sludge area.

3. Sludge treatment areas. This zone located in northwest mainly covers sludge thickener, digester sludge, dehydration, accidents pile of mud between the control room and other, which is a more intensive contaminated area of the plant. There is a green belt between front factory district and it. In the sludge zone established separately pursuant to deliver sand, slag, sludge, avoiding the effects on the environment.

Monomeric structures of sewage treatment plant are water pipe parts, water pumping station, wide screen, fine screen, swirling flow sedimentation tank, sedimentation tank I , primary clarifier distributor box and sludge pumping station, bio pool, sedimentation tank II, matches well and sludge pumping station, blower room, sludge thickening tank, sludge thickening machine room, sludge storage tank, digestion tank, sludge control room, homogeneous pool, concentrated pool, sludge dewatering room, biogas desulfurization tower, biogas storage cabinets, etc [1].

\section{ANALYSIS OF RISK AND HARMFUL FACTORS}

\subsection{Analysis of Risk Factors}

The hazards of the sewage treatment plant are identified by accident categories. Through analysis there are several possible risk factors as shown in Table (1).

\subsection{Analysis of Harmful Factors}

Through field visit the author found the sewage treatment plant exists two harmful factors (Table 2). 


\section{SAFETY EVALUATION OF WASTEWATER TREA TMENT PLANT}

\subsection{Evaluation unit division}

According to the major danger and harmful factors identification and evaluation of the large sewage treatment plant this safety assessment is divided into 7 units (Table $\mathbf{3}$ ).

\subsection{Safety Evaluation}

Safety checklist has features as great variety, wide application and be easy to use. People can make different checklist according to different requirements. The paper used safety check list to evaluate each unit of the sewage treatment plant. Evaluation results are shown in Table (4) to Table (10).

\subsection{Accident Tree Analysis}

Accident Tree Analysis use accidents that may occur or have occurred in the system as an analysis starting point and list the cause of accident events layer-by-layer using which could identify and evaluate the risk of various systems [7]. The paper will use ATA to evaluate the safety of electrical equipment in plant. Fig. (1) is the electric shock tree.

Simplify the accident tree.

$\mathrm{T}=\mathrm{A}_{1} \cdot \mathrm{A}_{2} \cdot \mathrm{A}_{3}$

$=\left(\mathrm{A}_{4}+\mathrm{A}_{5}\right) \cdot \mathrm{A}_{2} \cdot \mathrm{A}_{3}$

$=\left(\mathrm{X}_{1}+\mathrm{X}_{2}+\mathrm{X}_{3}+\mathrm{X}_{4}+\mathrm{X}_{5}+\mathrm{X}_{6}\right) \cdot\left(\mathrm{X}_{7}+\mathrm{X}_{8}\right) \cdot\left(\mathrm{X}_{9}+\mathrm{X}_{10}+\mathrm{X}_{11}\right)$

$=\mathrm{X}_{1} \bullet \mathrm{X}_{7} \bullet \mathrm{X}_{9}+\mathrm{X}_{2} \bullet \mathrm{X}_{7} \bullet \mathrm{X}_{9}+\mathrm{X}_{3} \bullet \mathrm{X}_{7} \bullet \mathrm{X}_{9}+\mathrm{X}_{4} \bullet \mathrm{X}_{7} \bullet \mathrm{X}_{9}+\mathrm{X}_{5} \bullet \mathrm{X}_{7} \bullet \mathrm{X}_{9}+$

$\mathrm{X}_{6} \bullet \mathrm{X}_{7} \bullet \mathrm{X}_{9}+\mathrm{X}_{1} \bullet \mathrm{X}_{8} \bullet \mathrm{X}_{9}+\mathrm{X}_{2} \bullet \mathrm{X}_{8} \bullet \mathrm{X}_{9}+\mathrm{X}_{3} \bullet \mathrm{X}_{8} \bullet \mathrm{X}_{9}+\mathrm{X}_{4} \bullet \mathrm{X}_{8} \bullet \mathrm{X}_{9}+$

$\mathrm{X}_{5} \cdot \mathrm{X}_{8} \cdot \mathrm{X}_{9}+\mathrm{X}_{6} \cdot \mathrm{X}_{8} \bullet \mathrm{X}_{9}+\mathrm{X}_{1} \cdot \mathrm{X}_{7} \cdot \mathrm{X}_{10}+\mathrm{X}_{2} \cdot \mathrm{X}_{7} \cdot \mathrm{X}_{10}+\mathrm{X}_{3} \cdot \mathrm{X}_{7} \cdot \mathrm{X}_{10}+$

$\mathrm{X}_{4} \bullet \mathrm{X}_{7} \bullet \mathrm{X}_{10}+\mathrm{X}_{5} \bullet \mathrm{X}_{7} \bullet \mathrm{X}_{10}+\mathrm{X}_{6} \bullet \mathrm{X}_{7} \bullet \mathrm{X}_{10}+\mathrm{X}_{1} \bullet \mathrm{X}_{8} \bullet \mathrm{X}_{10}+\mathrm{X}_{2} \bullet \mathrm{X}_{8} \bullet \mathrm{X}_{10}+$

$\mathrm{X}_{3} \cdot \mathrm{X}_{8} \bullet \mathrm{X}_{10}+\mathrm{X}_{4} \cdot \mathrm{X}_{8} \bullet \mathrm{X}_{10}+\mathrm{X}_{5} \cdot \mathrm{X}_{8} \bullet \mathrm{X}_{10}+\mathrm{X}_{6} \cdot \mathrm{X}_{8} \bullet \mathrm{X}_{10}+\mathrm{X}_{1} \bullet \mathrm{X}_{7} \bullet \mathrm{X}_{11}+$

$\mathrm{X}_{2} \bullet \mathrm{X}_{7} \bullet \mathrm{X}_{11}+\mathrm{X}_{3} \bullet \mathrm{X}_{7} \bullet \mathrm{X}_{11}+\mathrm{X}_{4} \bullet \mathrm{X}_{7} \bullet \mathrm{X}_{11}+\mathrm{X}_{5} \bullet \mathrm{X}_{7} \bullet \mathrm{X}_{11}+\mathrm{X}_{6} \bullet \mathrm{X}_{7} \bullet \mathrm{X}_{11}+$

$\mathrm{X} 1 \bullet \mathrm{X}_{8} \bullet \mathrm{X}_{11}+\mathrm{X}_{2} \bullet \mathrm{X}_{8} \bullet \mathrm{X}_{11}+\mathrm{X}_{3} \bullet \mathrm{X}_{8} \bullet \mathrm{X}_{11}+\mathrm{X}_{4} \bullet \mathrm{X}_{8} \bullet \mathrm{X}_{11}+\mathrm{X}_{5} \bullet \mathrm{X}_{8} \bullet \mathrm{X}_{11}+$

$\mathrm{X}_{6} \cdot \mathrm{X}_{8} \cdot \mathrm{X}_{11}$

Table 1. Risk factors analysis of the sewage treatment plant.

\begin{tabular}{|c|c|c|}
\hline No. & Risk Factor & Explanation \\
\hline 1 & $\begin{array}{l}\text { Poisoning and } \\
\text { Suffocation }\end{array}$ & $\begin{array}{l}\text { There is } \mathrm{H} 2 \mathrm{~S} \text { in several units such as format grid, grit, sewage pumps, and mud storage pools. If operators inspect and } \\
\text { repair into these parts without ventilation it is more susceptible to poisoning and suffocation accident }[2,3] \text {. }\end{array}$ \\
\hline 2 & Electrical injuries & $\begin{array}{l}\text { The sewage treatment plants equipped with one variable power distribution room, two } 800 \mathrm{kV} \text {.A transformers, } 24 \text { sets of } \\
10 \mathrm{kV} \text { and } 0.4 \mathrm{kV} \text { switch cabinet, motor, cables, and lighting equipment. These devices often run in humid and corrosive } \\
\text { environment. It is prone to electrical injuries if there is improper operation, equipment failure or the grounding lightning } \\
\text { protection system is not safe }[4,5] .\end{array}$ \\
\hline 3 & Drowning & $\begin{array}{l}\text { The factory has many deep pools of depth is more than } 3 \mathrm{M} \text {. If the facility was flawed, protective measures are not in place, } \\
\text { workers in violation of, not wear anti-slip work boot the workers can be slipped into a sump during inspections or } \\
\text { operations. Especially in rain and snow weather it is most likely to lead to drowning accidents [3]. }\end{array}$ \\
\hline 4 & Fire and explosion & $\begin{array}{l}\text { Most construction materials of the sewage treatment plant are combustible, such as plastic tent material. Improper use of } \\
\text { pressure equipment may cause explosion such as fire extinguishers. In addition, in the sewage sludge treatment process } \\
\text { also produces flammable and explosive substances shouldn't be ignored, such as methane. }\end{array}$ \\
\hline 6 & Lifting injury & $\begin{array}{l}\text { Water pumping stations, return sludge pumping station and dehydration workshops are equipped with LX single girder } \\
\text { suspension crane. Locking devices, brakes, limit switches, or other safety device malfunction, loose hanging or people } \\
\text { under objects, rope break induced by overloading, oblique hanging or other illegal orders and illegal operations may cause } \\
\text { lifting injury }[3,6] \text {. }\end{array}$ \\
\hline
\end{tabular}

Table 2. Harmful factors analysis of sewage treatment plant.

\begin{tabular}{|c|c|l|}
\hline No. & Harmful factor & \multicolumn{1}{c|}{ Explanation } \\
\hline \hline 1 & Noise and vibration & $\begin{array}{l}\text { Noise in the sewage treatment plant was produced by shock, friction and collisions of the devices. Most noise is in low } \\
\text { and intermediate frequency and mainly concentrated in the water pumping stations, blower house and sludge dewatering } \\
\text { plant. }\end{array}$ \\
\hline 2 & $\begin{array}{c}\text { Non-ionizing } \\
\text { radiation }\end{array}$ & $\begin{array}{l}\text { Disinfection of the Sewage treatment plant is by ultraviolet. Ultraviolet made by high pressure pump light is non-ionizing } \\
\text { radiation. Direct exposure to ultraviolet light can cause eye and skin burns which destroy the body's immune system. }\end{array}$ \\
\hline
\end{tabular}


Table 3. Evaluation unit division.

\begin{tabular}{|c|c|l|}
\hline No. & Evaluation Unit & \multicolumn{1}{c|}{ Explanation } \\
\hline \hline 1 & Safety management unit & $\begin{array}{l}\text { Mainly evaluate safety management system, safety management organization, personnel qualifications, } \\
\text { emergency plans and others. }\end{array}$ \\
\hline 2 & Warning labels unit & $\begin{array}{l}\text { Mainly evaluate the setting of warning signs of workplace accidents that may occur, equipment, product } \\
\text { package, storage spaces, etc. }\end{array}$ \\
\hline 3 & Machinery and special equipment & $\begin{array}{l}\text { Mainly evaluate the daily usage, repair, maintenance, and operators' job qualifications of the machinery } \\
\text { and special equipment. }\end{array}$ \\
\hline 5 & Hoisting machinery unit & Mainly evaluate the daily operations and maintenance of hoisting machineries. \\
\hline 6 & Electrical injuries unit & $\begin{array}{l}\text { Mainly evaluate the electrical hazardous locations such as transformer room, power distribution room, } \\
\text { distribution cabinet, etc. }\end{array}$ \\
\hline 7 & Fire management unit & $\begin{array}{l}\text { Mainly evaluate the configuration and usage of fire equipment such as fire extinguishers, hydrants, fire } \\
\text { hose of contractures in the factory. }\end{array}$ \\
\hline
\end{tabular}

Table 4. Safety checklist of safety management unit.

\begin{tabular}{|c|c|c|}
\hline No. & Examine content & Results \\
\hline 2 & Safety conferences record & $\times$ \\
\hline 3 & Sound safety management agency and system & $\sqrt{ }$ \\
\hline 5 & Report the occupational disease hazard program & $\times$ \\
\hline 6 & Established occupational health files & $\times$ \\
\hline 7 & Occupational health checks during the pre-employment, on-the-job and indexed & $\sqrt{ }$ \\
\hline 11 & The heads and safety managers achieved certificates of safety education and training & $\sqrt{ }$ \\
\hline 12 & The heads and safety managers achieved certificates of safety education and training & $\sqrt{ }$ \\
\hline 13 & Archives of industrial injury accident is sound & $\mathrm{O}$ \\
\hline 14 & Electricians and pressure vessel operators operating rules & $\mathrm{O}$ \\
\hline 15 & Whether the stakeholders' safety management agreement is unified & $\sqrt{ }$ \\
\hline 16 & Perfect accidents and comprehensive rescue plan & $\sqrt{ }$ \\
\hline 17 & Emergency drill records & $\sqrt{ }$ \\
\hline
\end{tabular}


Table 5. Safety checklist of warning labels unit.

\begin{tabular}{|c|c|c|}
\hline No. & Examine content & Results \\
\hline 2 & Whether various types of pipes are identified & $\times$ \\
\hline 3 & Whether set up wind vanes in mud areas & $\sqrt{ }$ \\
\hline 5 & Whether there are electric shock warning labels at power distribution room and transformer room & $\sqrt{ }$ \\
\hline 6 & If there are toxic gas labels around the Sewage tank and water-into wells & $\sqrt{ }$ \\
\hline
\end{tabular}

Table 6. Safety checklist of machinery and special equipmentunit.

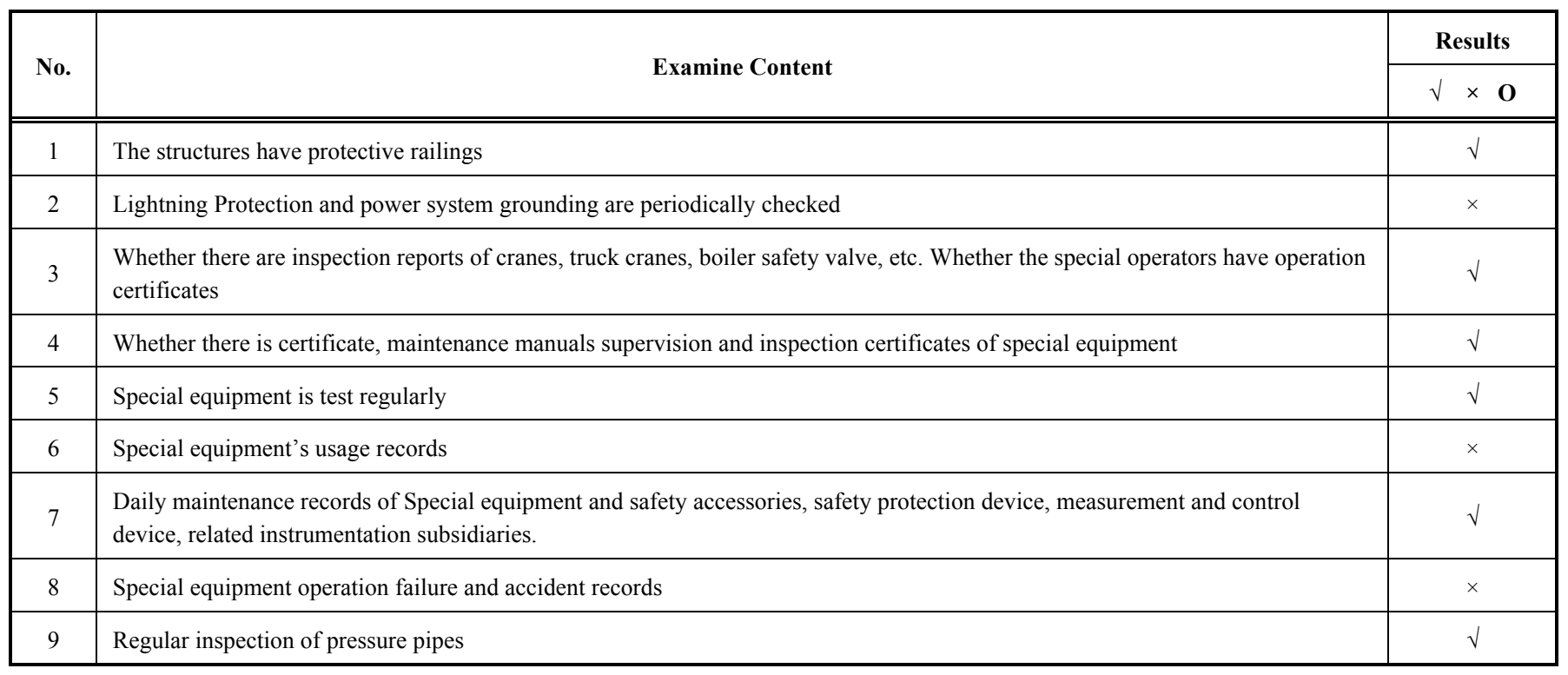

Table 7. Safety checklist of hoisting machinery unit.

\begin{tabular}{|c|c|c|}
\hline \multirow{2}{*}{ No. } & \multirow{2}{*}{ Examine content } & Results \\
\hline & & $\sqrt{ } \times \mathbf{O}$ \\
\hline 1 & Be lack of oil & $\mathrm{O}$ \\
\hline 2 & Whether the steel wire rope of crane is twining bad & $\sqrt{ }$ \\
\hline 4 & Limiter & $\sqrt{ }$ \\
\hline 5 & Loading identifications & $\sqrt{ }$ \\
\hline 6 & Anti-off clips at the end of wire rope & $\sqrt{ }$ \\
\hline 7 & Crane controlled switch is safe voltage & $\sqrt{ }$ \\
\hline
\end{tabular}


Table 8. Safety checklist of electrical injuries unit.

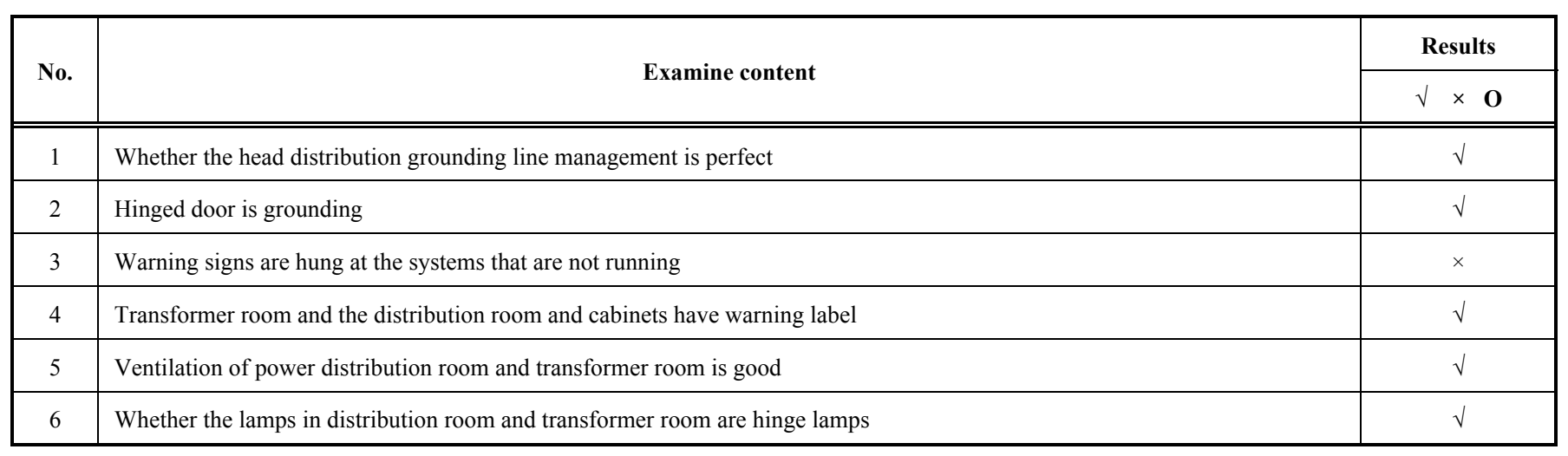

Table 9. Safety checklist of fire management unit.

\begin{tabular}{|c|c|c|}
\hline No. & Examine content & Results \\
\hline 2 & Whether the placement of each structure's fire hydrant is appropriate & $\sqrt{ }$ \\
\hline 3 & Whether the fire hydrants have fire hose & $\sqrt{ }$ \\
\hline 5 & Be lack of firefighting equipment & $\sqrt{ }$ \\
\hline
\end{tabular}

Table 10. Safety checklist of explosion safety management unit.

\begin{tabular}{|c|c|c|}
\hline No. & Examine content & $\sqrt{ } \times \mathbf{O}$ \\
\hline 2 & Eyewash in laboratory & $\sqrt{ }$ \\
\hline 3 & The sulfuric acid, nitric acid, hydrochloric acid and other corrosive liquids have a solid and reliable place measures & $\sqrt{ }$ \\
\hline 5 & Whether the gas tank is surrounded by solid walls & $\sqrt{ }$ \\
\hline 6 & The trachea of the anaerobic digester has tempering preventive device & $\sqrt{ }$ \\
\hline 7 & Offices in Mud control room & $\sqrt{ }$ \\
\hline 11 & The power blower and biogas blower are isolated & $\sqrt{ }$ \\
\hline 12 & The distance between gas cabinets and surrounding buildings meet the requirements & $\sqrt{ }$ \\
\hline 13 & Whether the gas tank has lighting & $\sqrt{ }$ \\
\hline 14 & Valves, stents number management of biogas systems & $\times$ \\
\hline 15 & Digester is equipped with gas masks & $\sqrt{ }$ \\
\hline 16 & Each engine room is well-ventilated & $\mathrm{O}$ \\
\hline
\end{tabular}


Table 10. contd....

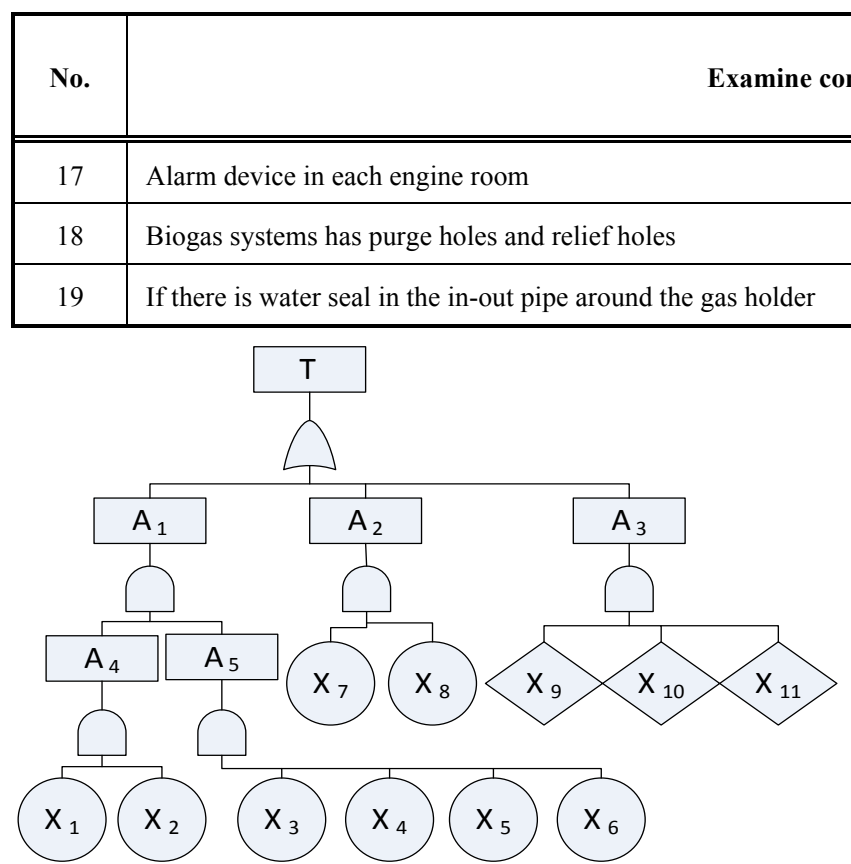

Fig. (1). Electric Shock Tree.

In Fig. (1), every symbol is expressed as follows:

$\mathrm{T}$--- electric shock casualty;

$A_{1}$--- equipment and facilities are charged;

$A_{2}$--- safety devices do not work;

$\mathrm{A}_{3}$--- ground protection failure;

$\mathrm{A}_{4}$--- power facilities are charged;

$\mathrm{A}_{5}$--- equipment enclosure is charged;

$\mathrm{X}_{1}$--- switch leakage;

$\mathrm{X}_{2}$--- line leakage;

$\mathrm{X}_{3}$--- heating element deformed and charged;

$\mathrm{X}_{4}$--- motor leakage;

$\mathrm{X}_{5}$--- conductive material makes power and equipment connected;

$\mathrm{X}_{6}$--- control electrical appliance leakage;

$\mathrm{X}_{7}$--- did not use safety equipment;

$\mathrm{X}_{8}$--- insulation failure due to dirty and wet;

$\mathrm{X}_{9}$--- protective grounding failure;

$\mathrm{X}_{10}$--- poor grounding;

$\mathrm{X}_{11}$--- ungrounded;

It gets 36 minimal cut sets by simplifying the accident tree.

$\mathrm{k}_{1}=\left\{\mathrm{X}_{1}, \mathrm{X}_{7}, \mathrm{X}_{9}\right\}$

$\mathrm{k}_{3}=\left\{\mathrm{X}_{3}, \mathrm{X}_{7}, \mathrm{X}_{9}\right\}$

$\mathrm{k}_{2}=\left\{\mathrm{X}_{2}, \mathrm{X}_{7}, \mathrm{X}_{9}\right\}$

$\mathrm{k}_{5}=\left\{\begin{array}{lll}\mathrm{X}_{5}, & \mathrm{X}_{7}, \mathrm{X}_{9}\end{array}\right\}$

$\mathrm{k}_{4}=\left\{\mathrm{X}_{4}, \mathrm{X}_{7}, \mathrm{X}_{9}\right\}$

$\mathrm{k}_{7}=\left\{\begin{array}{lll}\mathrm{X}_{1}, & \mathrm{X}_{8}, \mathrm{X}_{9}\end{array}\right\}$

$\mathrm{k}_{6}=\left\{\begin{array}{lll}\mathrm{X}_{6}, & \mathrm{X}_{7}, \mathrm{X}_{9}\end{array}\right\}$

$\mathrm{k}_{8}=\left\{\mathrm{X}_{2}, \mathrm{X}_{8}, \mathrm{X}_{9}\right\}$

$\begin{array}{ll}\mathrm{k}_{9}=\left\{\mathrm{X}_{3}, \mathrm{X}_{8}, \mathrm{X}_{9}\right\} & \mathrm{k}_{10}=\left\{\mathrm{X}_{4}, \mathrm{X}_{8}, \mathrm{X}_{9}\right\} \\ \mathrm{k}_{11}=\left\{\mathrm{X}_{5}, \mathrm{X}_{8}, \mathrm{X}_{9}\right\} & \mathrm{k}_{12}=\left\{\mathrm{X}_{6}, \mathrm{X}_{8}, \mathrm{X}_{9}\right\} \\ \mathrm{k}_{13}=\left\{\mathrm{X}_{1}, \mathrm{X}_{7}, \mathrm{X}_{10}\right\} & \mathrm{k}_{14}=\left\{\mathrm{X}_{2}, \mathrm{X}_{7}, \mathrm{X}_{10}\right\} \\ \mathrm{k}_{15}=\left\{\mathrm{X}_{3}, \mathrm{X}_{7}, \mathrm{X}_{10}\right\} & \mathrm{k}_{16}=\left\{\mathrm{X}_{4}, \mathrm{X}_{7}, \mathrm{X}_{10}\right\} \\ \mathrm{k}_{17}=\left\{\mathrm{X}_{5}, \mathrm{X}_{7}, \mathrm{X}_{10}\right\} & \mathrm{k}_{18}=\left\{\mathrm{X}_{6}, \mathrm{X}_{7}, \mathrm{X}_{10}\right\} \\ \mathrm{k}_{19}=\left\{\mathrm{X}_{1}, \mathrm{X}_{8}, \mathrm{X}_{10}\right\} & \mathrm{k}_{20}=\left\{\mathrm{X}_{2}, \mathrm{X}_{8}, \mathrm{X}_{10}\right\} \\ \mathrm{k}_{21}=\left\{\mathrm{X}_{3}, \mathrm{X}_{8}, \mathrm{X}_{10}\right\} & \mathrm{k}_{22}=\left\{\mathrm{X}_{4}, \mathrm{X}_{8}, \mathrm{X}_{10}\right\} \\ \mathrm{k}_{23}=\left\{\mathrm{X}_{5}, \mathrm{X}_{8}, \mathrm{X}_{10}\right\} & \mathrm{k}_{24}=\left\{\mathrm{X}_{6}, \mathrm{X}_{8}, \mathrm{X}_{10}\right\} \\ \mathrm{k}_{25}=\left\{\mathrm{X}_{1}, \mathrm{X}_{7}, \mathrm{X}_{11}\right\} & \mathrm{k}_{26}=\left\{\mathrm{X}_{2}, \mathrm{X}_{7}, \mathrm{X}_{11}\right\} \\ \mathrm{k}_{27}=\left\{\mathrm{X}_{3}, \mathrm{X}_{7}, \mathrm{X}_{11}\right\} & \mathrm{k}_{28}=\left\{\begin{array}{ll}\mathrm{X}_{4}, \mathrm{X}_{7}, \mathrm{X}_{11}\end{array}\right\} \\ \mathrm{k}_{29}=\left\{\mathrm{X}_{5}, \mathrm{X}_{7}, \mathrm{X}_{11}\right\} & \mathrm{k}_{30}=\left\{\mathrm{X}_{6}, \mathrm{X}_{7}, \mathrm{X}_{11}\right\} \\ \mathrm{k}_{31}=\left\{\mathrm{X}_{1}, \mathrm{X}_{8}, \mathrm{X}_{11}\right\} & \mathrm{k}_{32}=\left\{\mathrm{X}_{2}, \mathrm{X}_{8}, \mathrm{X}_{11}\right\} \\ \mathrm{k}_{33}=\left\{\mathrm{X}_{3}, \mathrm{X}_{8}, \mathrm{X}_{11}\right\} & \mathrm{k}_{34}=\left\{\mathrm{X}_{4}, \mathrm{X}_{8}, \mathrm{X}_{11}\right\} \\ \mathrm{k}_{35}=\left\{\mathrm{X}_{5}, \mathrm{X}_{8}, \mathrm{X}_{11}\right\} & \mathrm{k}_{36}=\left\{\mathrm{X}_{6}, \mathrm{X}_{8}, \mathrm{X}_{11}\right\}\end{array}$

Structure importance of each basic event:

$\mathrm{I}_{\mathrm{k}}(1)=\mathrm{I}_{\mathrm{k}}(2)=\mathrm{I}_{\mathrm{k}}(3)=\mathrm{I}_{\mathrm{k}}(4)=\mathrm{I}_{\mathrm{k}}(5)=\mathrm{I}_{\mathrm{k}}(6)=1 / 36 \times(1 / 3 \times 6)=1 / 18$

$\mathrm{I}_{\mathrm{k}}(9)=\mathrm{I}_{\mathrm{k}}(10)=\mathrm{I}_{\mathrm{k}}(11)=1 / 36 \times(1 / 3 \times 12)=1 / 9$

$\mathrm{I}_{\mathrm{k}}(7)=\mathrm{I}_{\mathrm{k}}(8)=1 / 36 \times(1 / 3 \times 18)=1 / 6$

Sorting:

$\mathrm{I}_{\mathrm{k}}(7)=\mathrm{I}_{\mathrm{k}}(8)>\mathrm{I}_{\mathrm{k}}(9)=\mathrm{I}_{\mathrm{k}}(10)=\mathrm{I}_{\mathrm{k}}(11)>\mathrm{I}_{\mathrm{k}}(1)=\mathrm{I}_{\mathrm{k}}(2)=\mathrm{I}_{\mathrm{k}}(3)=$ $\mathrm{I}_{\mathrm{k}}(4)=\mathrm{I}_{\mathrm{k}}(5)=\mathrm{I}_{\mathrm{k}}(6)$

In order to prevent electric shock the first is to use various safety equipment and control leakage incidents due to dirty or wet. Second is to check other events that can lead to electric shock. Only the timely control of the basic events could prevent electric shock accidents fundamentally.

\section{CONCLUSION}

According to safety assessment of large wastewater treatment plants, get the following conclusions:

(1) The major risk factors in the production process of the construction projects are poisoning and suffocation, electrical injuries, drowning, fire and explosion, mechanical injury, lifting injury; Harmful factors are noise and vibration, non-ionizing radiation. The main risk factors which should be focused on are poisoning and suffocation, electrical injuries, fire and explosion.

(2) Using safety checklist method to using evaluate the seven safety evaluation units found that the there are many safety risks in the factory. Sewage treatment plant should set specific safety management agencies, full-time safety 
officer, establish and improve the safe production responsibility system, imply the head's safety responsibilities, develop safety management regulations and operation procedures, develop safety emergency rescue plan and exercise regularly, ensure safety.

(3) In order to prevent electric shock accident first is to use the safety equipment and control leakage events due to dirty and wet.

\section{CONFLICT OF INTEREST}

The authors confirm that this article content has no conflict of interest.

\section{REFERENCES}

[1] X.D. Liu, Preliminary Design of Sewage Treatment Project in Shijiazhuang, Shijiazhuang, 2000, pp. 36-45.

[2] China Tianchen Engineering Corporation. Code for Design of Chemical Enterprise Safety and Health, China, 2014.

[3] F.W. Li, and M.P. Yang, "Research on safe operation of municipal wastewater treatment plant", China Safety Science Journal, vol. 19, pp. 10-16, 2009

[4] S.Y. Liu, Safety Evaluation, Beijing, 2010, pp. 126-138.

[5] Construction Department of Zhejiang Province, Code of Acceptance of Construction Quality of Electrical Installation Building, China, 2011.

[6] National Technical Committee of Standardization of Hoisting Machinery, Safety Regulations for Cranes, China, 2010.

[7] J. L. Zhang, and G. Z. Cui, Safety System Engineering. Beijing, 2002, pp. 58-69.

\section{ACKNOWLEDGEMENTS}

Declared none.

Received: May 26, 2015

Revised: July 14, 2015

Accepted: August 10,2015

(C) Ping et al.; Licensee Bentham Open.

This is an open access article licensed under the terms of the (https://creativecommons.org/licenses/by/4.0/legalcode), which permits unrestricted, noncommercial use, distribution and reproduction in any medium, provided the work is properly cited. 